\title{
ВИКОРИСТАННЯ МАЙСТЕР-КЛАСІВ ПІД ЧАС ПРОВЕДЕННЯ ЦИКЛІВ ТЕМАТИЧНОГО УДОСКОНАЛЕННЯ НА КАФЕДРІ ПАТОЛОГІЧНОЇ АНАТОМІЇ
}

\author{
I. I. Yakovtsova, A. E. Oliynik, O. V. Dolhaia \\ Kharkiv Medical Academy of Postgraduate Education

\section{USE OF MASTER CLASSES DURING CYCLES OF THEMATIC IMPROVEMENT AT THE DEPARTMENT OF PATHOLOGICAL ANATOMY}

\begin{abstract}
Анотація. Заклади післядипломної медичної освіти в сучасній парадигмі медичної та освітянської реформи повинні додавати до традиційних схем навчання новітні технології викладання. Завданням закладів післядипломної медичної освіти є створення конкурентного освітнього продукту, який має суттєво поліпшити професійний рівень лікарів. Патологічна анатомія, як медична спеціальність, потребує не тільки глибоких теоретичних знань, а й досить специфічних практичних навичок. Тому усталені форми навчання (лекції, семінари, практичні заняття) значно поступаються за рівнем ефективності майстер-класам. Ця форма навчання поєднує в собі всі найкращі риси перерахованих типів занять, без зайвого витрачання часу і з максимальним рівнем візуалізації навчального процесу. Крім того, враховуючи певний кадровий голод у спеціальності «Патологічна анатомія», лікаріпатологоанатоми не завжди мають змогу витратити достатньо часу на довготривалий цикл підвищення кваліфікації. Тоді як вони можуть обрати ті теми майстер-класів, в ознайомленні з якими мають потребу, що диктується виробничою необхідністю. Стаття передає досвід використання майстер-класів під час післядипломного навчання лікарів-патологоанатомів. У ній надано інформацію щодо нормативно-правової бази проведення таких занять, наведено схему проведення майстер-класу на прикладі конкретної теми. Автори розробили алгоритм проведення майстер-класів з урахуванням специфіки викладання патологічної анатомії в закладах післядипломної освіти. Дані зворотного зв’язку зі слухачами свідчать про вельми позитивне сприйняття цієї форми навчання. Це доводить, що майстер-клас - одна з найефективніших форм професійного навчання лікарів, яка має обов'язково застосовуватися закладами післядипломної освіти. Кафедра патологічної анатомії ХМАПО має намір постійно збільшувати арсенал тем майстер-класів, наповнювати їх сучасним контентом, а також впроваджувати інші ефективні та креативні методики навчання.
\end{abstract}

Ключові слова: майстер-клас; післядипломна освіта; патологічна анатомія; лікарі-патологоанатоми.

Abstract. Institutions of postgraduate medical education in the modern paradigm of medical and educational reform should add the latest teaching technologies into the traditional teaching schemes. The task of institutions of postgraduate medical education is to create a competitive educational product that should significantly improve the professional level of doctors. Pathology, as a medical specialty, requires not only deep theoretical knowledge, but also very specific practical skills. Therefore, the established forms of training (lectures, seminars, practical classes) are significantly lower in terms of efficiency for master classes. This form of training combines all the best features of the listed types of classes, without having to waste time and with the maximum level of visualization of the educational process. In addition, taking into account a certain staff famine in the pathology, doctors-pathologists are not always able to spend enough time for a long-term training cycle. While they can choose the themes of the master classes, in familiarizing with the need, dictated by the production necessity. The article conveys the experience of using master classes during postgraduate training of pathologists. It provided information on the legal framework for conducting such classes, the scheme of conducting a master class on an example of a specific topic is given. The authors developed an algorithm for conducting master classes taking into account the specifics of teaching pathological anatomy in institutions of postgraduate education. The feedback from the listeners indicates a very positive perception of this form of learning. This proves that the master class is one of the most effective forms of vocational training of doctors, which must be applied by institutions of postgraduate education. The Department of Pathological Anatomy of KhMAPO intends to constantly increase the arsenal of those master classes, fill them with contemporary content, and also introduce other effective and creative teaching methods.

Key words: master-class; postgraduate education; pathology; pathologist. 
Вступ. Кафедрою патологічної анатомії ХМАПО щорічно проводиться близько 10 циклів тематичного удосконалення для представників різних медичних спеціальностей, але насамперед - для лікарів-патологоанатомів. Вимоги сучасного життя до післядипломної підготовки фахівців-патологоанатомів потребують від них не тільки глибоких теоретичних знань, а й можливості їх застосування, насамперед, під час проведення гістологічних досліджень. Цього можна досягти тільки під час взаємодії з висококваліфікованими фахівцями [4]. Оптимальною формою такої взаємодії на сьогодні є майстер-клас, і фактор «взаємо» тут особливо важливий, адже пряме відтворення, механічне повторення професійних досягнень сьогодні практично безперспективне, воно не дасть належного ефекту [5].

Майстер-клас (від англійського masterclass: master - кращий у якій-небудь області + class - заняття, урок) - сучасна форма проведення навчального тренінгу для відпрацювання практичних навичок за різними методиками і технологіями 3 метою підвищення професійного рівня та обміну передовим досвідом учасників, розширення кругозору та залучення до новітніх галузей знання [3]. Майстер-клас - це ефективна форма передачі знань і вмінь, обміну досвідом навчання і виховання, центральною ланкою якої є демонстрація оригінальних методів освоєння певного змісту за активної ролі всіх учасників заняття. Майстер-клас відрізняється від звичайного (типового) семінару тим, що під час майстер-класу провідний спеціаліст розповідає i, що ще більш важливо, показує, як застосовувати на практиці нову технологію або метод. Головний принцип майстер-класу: «Я знаю, як це робити. Я навчу вас» [1].

Тренер - це фахівець у системі післядипломної освіти, який здійснює процес навчання (coaching process), сприяє успішному досягненню визначеної професійної мети, отриманню позитивно сформульованих інноваційних професійно значущих результатів. Тренер компетентно і тактовно допомагає відокремити та сформулювати професійну проблему, визначити цілі, шляхи та засоби їх досягнення, не намагаючись змінити людину, а розкриваючи її природний потенціал. Це вчитель, здатний сформувати професіонала, компетентного фахівця [2].

Мета статті - висвітлити досвід викладачів кафедри щодо використання майстер-класів для поліпшення оволодіння слухачами циклів тематичного удосконалення певних тем патологічної анатомії та онкоморфології.
Теоретична частина. Майстер-клас $є$ найефективнішою формою професійного навчання, підвищення фахової майстерності осіб, які навчаються, на основі освоєння перспективного досвіду в галузі охорони здоров'я.

При проведенні майстер-класів кафедра спирається на декілька нормативних документів. Насамперед, це Положення про майстер-клас, розроблене відповідно до чинного законодавства України, Статуту Харківської медичної академії післядипломної освіти (ХМАПО). Крім того, при розробці та проведенні майстер-класів необхідно керуватися законами України «Про освіту», «Про вищу освіту», Постановою Кабінету Міністрів України від 28.03.2018 p. № 302 «Про затвердження Положення про безперервний професійний розвиток фахівців у сфері охорони здоров' я», Постановою Кабінету Мiністрів України «Про схвалення Стратегії розвитку медичної освіти в Україні», нормативними документами Міністерства охорони здоров'я України, нормативними документами Міністерства освіти і науки України, галузевими стандартами вищої освіти, Політикою у сфері якості ХМАПО, Політикою забезпечення якості освітньої діяльності та якості вищої освіти ХМАПО відповідно до стандартів та рекомендацій забезпечення якості в Європейському просторі вищої освіти, наказами ректора, рішеннями вченої ради ХМАПО.

Метою проведення майстер-класу є вдосконалення професійних компетентностей лікарівпатологоанатомів після здобуття ними вищої освіти та післядипломної освіти в інтернатурі. Сучасному фахівцю необхідно підтримувати або покращувати стандарти професійної діяльності відповідно до потреб галузі охорони здоров'я та прискорити процес трансформації перспективного досвіду в практичну діяльність, збагативши його інноваційними методами, підходами, технологіями для вирішення проблеми.

Крім того, цей вид взаємодії має привести до створення цілісної системи новітніх методик професійного навчання на основі вивчення, апробації кращого досвіду та його впровадження 3 використанням інноваційних технологій. Важливою $€$ пропаганда перспективних моделей досвіду з актуальних проблем у галузі онкоморфології, піднесення ефективності якісної патологоанатомічної діагностики.

Майстер-клас проводиться у вигляді інтегрованого лекційно-практичного заняття, бо в дисципліні «Патологічна анатомія» має бути максимально 
щільно поєднаний теоретичний матеріал і практична робота з мікропрепаратами.

Майстер-класи організовані в навчальних приміщеннях кафедри патологічної анатомії, оснащених відповідними технічними засобами навчання (бінокулярні мікроскопи Carl Zeiss Primo Star 3 мікрофотовідеокамерою, яка за допомогою відповідного програмного забезпечення та мультимедійного проектора надає можливість демонструвати зображення на великий екран). Це створює умови для групового аналізу мікроскопічної картини, що було майже неможливим у традиційній схемі роботи з гістологічними препаратами.

Структура надана на прикладі схеми проведення майстер-класу з діагностики пухлин молочної залози.

- Вступ (окреслюється проблема, обгрунтовується актуальність теми, конкретизуються мета, завдання майстер-класу).

- Анонсується тематика засідань та зміст роботи слухачів між засіданнями. Обов'язковим моментом $\epsilon$ приділення уваги сучасним методикам діагностики, зокрема імуногістохімічним.

- Презентація досвіду тренером: коротко окреслюються сучасні класифікаційні схеми пухлин молочної залози, описуються власні досягнення в діагностиці; доводиться результативність діяльності, яка свідчить про ефективність застосованого підходу, визначаються проблеми та перспективи в роботі тренера.

- Представлення системного алгоритму для діагностики пухлин молочної залози: описується система заходів збирання та аналізу даних, визначаються основні прийоми роботи, які тренер буде демонструвати слухачам.

- Проведення «імітаційної гри»: тренер демонструє на великому екрані мікропрепарати пухлин молочної залози і встановлює діагноз згідно 3 сучасними класифікаціями з використанням тих діагностичних алгоритмів, з якими слухачі познайомилися раніше; слухачі одночасно грають дві ролі: учнів експериментальної групи та експертів, присутніх на відкритому заході.

- Моделювання: слухачі виконують самостійну роботу з власної діагностики пухлин у режимі технології тренера; тренер виконує роль консультанта, організовує самостійну роботу слухачів i керує нею.

- Афішування - представлення виконаних робіт - встановлених діагнозів за дослідженими мікропрепаратами.
- Рефлексія: проводиться дискусія за результатами спільної діяльності слухачів і тренера.

Проведення майстер-класів здійснюється кафедрою на основі програм та річних планів, укладених згідно з планом роботи академії на відповідний календарний рік.

Програма майстер-класу погоджується з навчально-методичним кабінетом навчально-методичного відділу академії. У разі проведення майстер-класу на міжнародному рівні його програма погоджується з відділом науки та відділом з міжнародних зв'язків ХМАПО. Кількість занять майстер-класу визначається з врахуванням поставленої теми, мети й завдань і може варіюватися від 1 до 5.

За участь слухачів у майстер-класі нараховуються бали безперервного професійного розвитку фахівців у сфері охорони здоров'я. За результатами участі в майстер-класі учасникам видаються сертифікати встановленого зразка. По закінченні циклу тематичного удосконалення, під час якого проводився майстер-клас, проводиться анкетування слухачів з метою визначення професійних потреб і думок щодо актуальності його теми, якості та ефективності проведення.

Безпосереднє керівництво проведенням майстер-класу здійснює завідувач кафедри. Навчально-методичний супровід програм та педагогічні технології, за якими проводиться майстер-клас, відстежує навчально-методичний кабінет навчально-методичного відділу ХМАПО. Відділ управління якістю освіти проводить моніторинг і аналізує ефективність роботи майстер-класів за даними анкетування слухачів, надає їх організаторам постійну методичну допомогу, вивчає i презентує кращий досвід їх роботи, сприяє популяризації авторської методичної системи організаторів майстер-класу.

Висновки та перспективи подальших досліджень. Основні переваги майстер-класу - це унікальне поєднання: короткої теоретичної частини, індивідуальної роботи, спрямованої на набуття i закріплення практичних знань і навичок. У технології проведення майстер-класу головне не повідомити і освоїти інформацію, а передати способи діяльності, чи то прийом, метод, методика, чи то технологія. Використання майстер-класів під час проведення циклів тематичного удосконалення, за результатами опитування слухачів, приводить до значного поліпшення діагностики пухлин різних локалізацій завдяки чіткій алгоритмізації технологічного процесу встановлення діагнозу. 
Необхідно зазначити, що майстер-клас може проводитися як у рамках циклів тематичного удосконалення чи підвищення кваліфікації, так і епізодичний методичний захід науково-методичних конференцій, шкіл, тренінгів, вебінарів, засідань

\section{Список літератури}

1. Лошицька О. Л. Майстер-клас у системі роботи 3 педагогічними кадрами : метод. посіб. / О. Л. Лошицька. - Ірпінь, 2015. - 40 с.

2. Положення про майстер-клас Харківської медичної академії післядипломної освіти / Міністерство охорони здоров’я України, Харківська медична академія післядипломної освіти. - X., 2018. - 10 с.

3. Belay H. T. Workshops: An important element in medical education / H. T. Belay, B. O. Ruairc, A. Guerandel // BJPsych Advances. - 2019. - No. 25. - P. 7-13.

\section{References}

1. Loshytska, O.L. (2015). Maister-klas u systemi roboty z pedahohichnymy kadramy: metodychnyi posibnyk (Irpin) [Master class in the system of work with pedagogical staff: a methodical manual]. Irpin [in Ukrainian].

2. (2018). Polozhennia pro maister-klas Kharkivskoi medychnoi akademii pisliadyplomnoi osvity [Regulations for workshops of Kharkiv Medical Academy of Postgraduate Education]. Ministry of Health of Ukraine. Kharkiv: Kharkiv Medical Academy of Postgraduate Education [in Ukrainian].

3. Belay, H.T., Ruairc, B.O., \& Guerandel, A. (2019). Workshops: An important element in medical education. BJPsych. Advances, 25, 7-13. doi:10.1192/bja.2018.41. вчених рад факультетів та вченої ради академії тощо. Кафедра патологічної анатомії ХМАПО має намір постійно збільшувати арсенал тем майстеркласів, використовуючи як найсучасніші наукові дані, так і результати власних розробок.

4. Does a one-day workshop improve clinical faculty's comfort and behaviour in practising and teaching evidencebased medicine? A Canadian mixed methods study / D. Allen, J. Abourbih, M. Maar [et al.] // BMJ Open. - 2017. No. 7. doi:doi:10.1136/ bmjopen-2016-015174.

5. Yost J. Evaluating the impact of an intensive education workshop on evidence-informed decision making knowledge, skills, and behaviours: A mixed methods study / J. Yost, D. Ciliska, M. Dobbins // BMC Medical Education. - 2014. - No. 14. doi:https://doi.org/10.1186/14726920-14-13.

4. Allen, D., Abourbih, J., Maar, M., Boesch, L., Goertzen, J., \& Cervin, C. (2017). Does a one-day workshop improve clinical faculty's comfort and behaviour in practising and teaching evidencebased medicine? A Canadian mixed methods study. BMJ Open, (7). doi:doi:10.1136/ bmjopen-2016-015174.

5. Yost, J., Ciliska, D., \& Dobbins, M. (2014). Evaluating the impact of an intensive education workshop on evidence-informed decision making knowledge, skills, and behaviours: A mixed methods study. BMC Medical Education, 14 (1). doi:https://doi.org/10.1186/1472-692014-13. 